\title{
An assessment of bovine herpes virus 4 as a causative agent in abortions and neonatal death
}

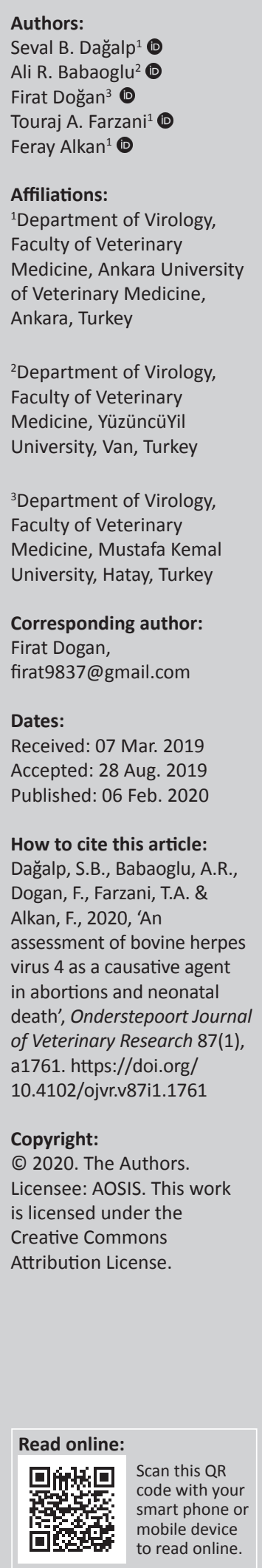

Numerous viruses, including bovine viral diarrhoea virus (BVDV), bovine herpes virus 1 (BoHV-1) and bovine herpes virus 4 (BoHV-4), and other pathogens are the most common causes of reproductive disorders and are responsible for huge economic losses in livestock production. This study investigates the aetiological role of BoHV-4 in fertility problems such as abortions, stillbirth and birth with unviable calves. Retrospective samples from 38 animals, including 17 aborting cows, 17 aborted foetuses, three stillborn calves and one unviable newborn calf were analysed. The BoHV-4 genome was detected in $25(65.7 \%)$ animals by polymerase chain reaction. In 14 of these infected animals, we detected co-infection with BVDV, while the co-presence of BoHV-1 was also detected in one animal. In addition to the high prevalence of BoHV-4 genome in materials related to fertility problems, isolation of BoHV-4 from the brain of one stillborn calf indicated a causal link between BoHV-4 and fertility problems, such as abortion, stillbirths or birth with unviable calves.

Keywords: abortion; BoHV-4; cow; co-infection; viruses.

\section{Introduction}

Previous studies have identified several viruses associated with reproductive disorders in cattle, such as abortion, neonatal death and births with congenital abnormalities. In such cases, bovine viral diarrhoea virus (BVDV) and bovine herpes virus 1 (BoHV-1) (Czaplicki \& Thiry 1998; Kirkbride 1992; McKercher \& Wada 1964; Miller \& Van der Maaten 1987; Murray 1990; Schiefer 1974; Wellemans, Van Opdenbosch \& Mammerickx 1986) are often detected along with bovine herpes virus 4 (BoHV-4). The detection of BoHV-4 even in healthy cattle (Czaplicki \& Thiry 1998; Kirkbride 1992; Monge et al. 2006) makes the investigation of the epidemiology and pathogenetic mechanisms of this infection an interesting subject for researchers.

Bovine herpesvirus 4 (BoHV-4) is a member of the Rhadinovirus genus of the Gamma herpes virinae sub-family (ICTV 2017). Antigenically, closely related strains of BoHV-4 with similar restriction patterns form two main groups, namely, genotype 1 and genotype 2, which possibly correspond to the Movar-like and DN 599-like reference strains, respectively. Genotype 3 has also been reported recently (Verna et al. 2012). As with other herpes viruses, animals experimentally infected with BoHV-4 develop a latent infection, followed by virus reactivation and re-excretion after dexamethasone treatment and stress factors such as calving (Dubuisson et al. 1989). This virus naturally infects blood mononuclear cells, such as macrophages and monocytes, and displays a specific tropism towards vascular endothelia, mammary tissue, endometrium and foetal tissues. Clinical manifestations associated with BoHV-4 in cattle include postpartum metritis (Monge et al. 2006), abortion (Czaplicki \& Thiry 1998; Kirkbride 1992; Schiefer 1974; Wellemans et al. 1986), mastitis (Izumi et al. 2006; Miyano et al. 2004; Wellenberg et al. 2000), pneumonia, keratoconjunctivitis, encephalitis and diarrhoea in both natural and experimental infections (Goyal \& Naeem 1992; Thiry et al. 1990). Although most BoHV-4 isolates are considered mild pathogens or completely apathogenic for cattle, BoHV-4 antibodies have higher prevalence in abortion cases than in clinically asymptomatic cattle (AltamIranda et al. 2015; Naeem, Goyal \& Werdin 1989).

In Turkey, numerous studies have investigated BoHV-1 and BVDV as aetiological agents of fertility problems, such as abortion, and have conducted serological screening of antibodies against these agents (Alkan \& Burgu 1993; Alkan et al. 2005, 2009, 2018; Bilge-Dagalp et al. 2008; Oğuzoğlu et al. 2012; Tan et al. 2006). There have also been virological and serological studies on BoHV-4 infection. These studies show that BoHV-4 infection is very common and is increasing 
significantly in cattle herds in Turkey (Aslan, Azkur \& Gazyagc 2015; Bilge-Dagalp et al. 2007, 2008, 2011; Dağalp et al. 2010; Tuncer-Göktuna et al. 2016; Yildirim et al. 2011). However, there is no published data about the detection of BoHV-4 in samples from aborted foetuses and stillborn or unviable calves.

The present study investigates the presence of BoHV-4 genome in samples from aborting cows, aborted foetuses, stillborn calves and unviable calves to investigate the interaction between BoHV-4 and these fertility problems. It also investigated whether there is any significant association between co-infection of BoHV-4 and two other abortifacient pathogens, BVDV and BoHV-1.

\section{Materials and methods}

\section{Sampled animals}

We used retrospective samples from 38 animals submitted to our laboratory for routine diagnosis, including 17 aborted foetuses, four stillbirths or unviable calves and 17 aborting cows from four different cattle herds (totalling 500-700 animals). In total, the 26 samples from 17 cows comprised leukocytes $(n=15)$, vaginal swabs $(n=9)$ and placental materials $(n=2)$. Other samples comprised various tissues from foetuses aborted at seventh to eighth month of gestation and from stillborn or unviable calves (Table 1). To increase the possibility of detecting viruses, each sample from the same animal was tested for BoHV-4 by polymerase chain reaction (PCR) assay along with two other frequently detected pathogens in Turkey, namely, Bovine Herpes Virus 1 (BoHV-1) and BVDV.

\section{Viral nucleic acid extraction and polymerase chain reaction}

Extraction of deoxyribonucleic acid (DNA) for all samples was carried out according to Sambrook, Fritsch and Maniatis (1989). Total RNA was extracted using a high pure viral nucleic acid kit (Roche, Germany) according to the manufacturer's recommendations. Complementary DNA (cDNA) synthesis was performed using the First Strand cDNA Synthesis Kit (Thermo Scientific, United States) according to the manufacturer's protocol.

The primer sets specific for $g B$ of BoHV-4 F: (5'-CCCTTCTT TACCACCACCTACA-3') and R: (5'-TGCCATAGCAGAGA $\left.A A C A A T G A-3^{\prime}\right)$ (Goltz et al. 2004), $g$ C of BoHV-1 F: (5'-CTGC TGTTCGTAGCCCACAACG-3') and R: (5'-TGTGACTTGGT GCCCATGTCGC-3') (Van Engelenburg et al. 1993) and 5'-UTR of BVDV F: (5'-ATG CCC WTA GTA GGA CTA GCA-3') and R: (5'- TCA ACT CCA TGT GCC ATG TAC -3') (Vilcek et al. 1997) were used in the PCR techniques that are described elsewhere with some minor modifications (Wellenberg et al. 2001).

TABLE 1: Distribution of materials and animals tested and polymerase chain reaction results.

\begin{tabular}{|c|c|c|c|c|c|}
\hline \multirow[t]{2}{*}{ Herd No. } & \multirow[t]{2}{*}{ Animal No. } & \multirow[t]{2}{*}{ Animals sampled } & \multirow[t]{2}{*}{ Samples tested } & \multicolumn{2}{|c|}{ PCR results } \\
\hline & & & & BoHV-4 & Other pathogens \\
\hline \multirow[t]{15}{*}{1} & 1 & Aborted foetus & Lung, brain, liver & Lung, brain & BVDV \\
\hline & 2 & Stillbirth calf & Brain, spleen, lung, liver & Brain & BVDV \\
\hline & $3-4$ & Stillbirth calf & Spleen, lung, liver, brain & - & - \\
\hline & $5-7$ & Aborted foetus & Spleen, brain & - & BVDV \\
\hline & 8 & Aborted foetus & Spleen, liver, brain, lung & - & BVDV \\
\hline & 10 & Aborted foetus & Brain, kidney, spleen, liver, heart & Brain & BVDV \\
\hline & 11 & Aborted foetus & Liver, lung, brain, spleen & Liver, lung & - \\
\hline & 12 & Aborted foetus & Spleen, liver, brain, lung, kidney & - & BVDV \\
\hline & 13 & Aborted foetus & Brain, liver, kidney & Brain, liver, kidney & BVDV \\
\hline & 14 & Aborted foetus & Brain, liver, kidney & Brain, liver, kidney & - \\
\hline & $15-16$ & Aborting cows & Leukocyte & - & - \\
\hline & 17 & Aborting cows & Leukocyte & Leukocyte & - \\
\hline & $19-26$ & Aborting cows & Vaginal swab, leukocyte & Vaginal swab & BVDV \\
\hline & 27 & Aborting cows & Vaginal swab, leukocyte & Vaginal swab & - \\
\hline & 28 & Aborting cows & Placental material & - & - \\
\hline \multirow[t]{6}{*}{ ॥ } & $29-30$ & Aborted foetus & Spleen, liver, brain, lung & - & \\
\hline & 31 & Aborted foetus & Liver, lung, spleen, brain & Brain & - \\
\hline & 32 & Aborted foetus & Liver, leukocyte, lung, spleen, brain & Leukocyte & BVDV \\
\hline & 33 & Aborted foetus & Brain, lung, liver, spleen & Spleen, liver, brain, lung & - \\
\hline & 34 & Aborted foetus & Spleen, liver, brain, lung, kidney & Spleen, liver & - \\
\hline & 35 & Aborting cows & Leukocyte & Leukocyte & - \\
\hline \multirow[t]{2}{*}{ III } & 36 & Calf birth with unviable & Spleen, liver, brain, lung, kidney & - & - \\
\hline & 37 & Aborting cows & Leukocyte & Leukocyte & - \\
\hline IV & 38 & Aborting cows & Placental material & Placental material & - \\
\hline Total & & $30 / 38(78.9 \%)$ & - & $25 / 38(65.7 \%)$ & $\begin{array}{l}19 / 38(50.9 \%) \text { fo } \\
1 / 38(2.6 \%) \text { for }\end{array}$ \\
\hline
\end{tabular}

PCR, polymerase chain reaction; BVDV, bovine viral diarrhoea virus; BoHV-4, bovine herpes virus 4; BoHV-1, bovine herpes virus 1. 
Specific PCR products (615 base pair (bp), $397 \mathrm{bp}$ and 288 bp of BoHV-4, BoHV-1 and BVDV, respectively) were visualised in transilluminator after electrophoresis in $1 \%$ agarose gel containing $10-\mathrm{mg} / \mathrm{mL}$ ethidium bromide.

\section{Ethical considerations}

This study was performed within the Scientific Research Projects of Ankara University (Project No.: 10B3338005).

\section{Results}

The PCR results are shown in Table 1, including the description of animals and related materials. Out of 38 animals, the BoHV-4 genome was detected in $25(65.7 \%)$ animals, with $14(36.8 \%)$ and one $(2.6 \%)$ co-infection rates for BVDV and BoHV-1, respectively. Moreover, out of 38 animals, $19(50.9 \%)$ animals were found to be positive for BVDV and one $(2.6 \%)$ animal was found to be positive for BoHV-1 (Table 1). The estimated rate of BoHV-4 positivity was $76.1 \%(16 / 21)$ for aborted foetuses and stillborn or unviable calves and $82.5 \%$ (14/17) for cattle (Table 2$)$. In total, $78.9 \%(30 / 38)$ of the sampled animals were positive for at least one of the tested viruses. The data showed that almost all tissues from an aborted foetus with BoHV-4 were found positive (Table 1).

\section{Discussion}

Bovine herpes virus 4 is a co-factor in cattle abortion cases along with other pathogens, including viruses, bacteria and protozoans. They also play a clear role in certain other reproductive disorders such as endometritis (ChastantMaillard 2015; Cvetojević et al. 2016; Frazier et al. 2002; Reed, Langpap \& Bergeland 1979). Researchers have, therefore, focussed on detecting BoHV-4 in semen, uterine and blood samples from aborting cows in herds with postpartum metritis (Cvetojević et al. 2016; Dağalp et al. 2012; Nikolin et al. 2007; Nikolin, Vesna \& Radosavljević 2008). However, the connection between BoHV-4 and abortions remains unclear because the virus has been isolated from both

TABLE 2: Results according to sampled herds and clinical cases.

\begin{tabular}{|c|c|c|c|c|c|c|c|c|}
\hline \multirow{2}{*}{$\begin{array}{l}\text { Animals } \\
(n=38)\end{array}$} & \multirow[t]{2}{*}{ Herds } & \multirow{2}{*}{$\begin{array}{l}\text { Tested } \\
\text { animals }\end{array}$} & \multirow[t]{2}{*}{ BoHV-4 } & \multicolumn{2}{|c|}{ Co-infections } & \multirow[t]{2}{*}{ BVDV } & \multicolumn{2}{|c|}{ Total } \\
\hline & & & & $\begin{array}{l}\text { BoHV-4 } \\
+ \text { BVDV }\end{array}$ & $\begin{array}{c}\text { BoHV-4 + } \\
\text { BoHV-1 }\end{array}$ & & $n$ & $\%$ \\
\hline \multirow{6}{*}{$\begin{array}{l}\text { Aborting cow } \\
(n=17)\end{array}$} & I & 14 & 2 & 8 & 1 & - & - & - \\
\hline & II & 1 & 1 & - & - & - & - & - \\
\hline & III & 1 & 1 & - & - & - & - & - \\
\hline & IV & 1 & 1 & - & - & - & - & - \\
\hline & Subtotal & 17 & 5 & 8 & 1 & - & 14 & 82.5 \\
\hline & & & & & 9 & & & \\
\hline \multirow{5}{*}{$\begin{array}{l}\text { Foetus and others } \\
(n=21)\end{array}$} & 1 & 14 & 2 & 5 & - & 5 & - & - \\
\hline & $\|$ & 6 & 3 & 1 & - & - & - & - \\
\hline & III & 1 & - & - & - & - & - & - \\
\hline & Subtotal & 21 & 5 & 6 & - & 5 & 16 & 76.1 \\
\hline & & \multicolumn{7}{|c|}{6} \\
\hline \multicolumn{2}{|l|}{ Total $(n=38)$} & & - & 14 & 1 & - & - & - \\
\hline \multirow{2}{*}{\multicolumn{2}{|c|}{$\begin{array}{l}n \\
\%\end{array}$}} & & 10 & \multicolumn{2}{|r|}{15} & 5 & 30 & - \\
\hline & & & 47.6 & \multicolumn{2}{|c|}{57.0} & 23.8 & - & 78.9 \\
\hline
\end{tabular}

diseased and healthy cattle (Czaplicki \& Thiry 1998; Deim, Szeredi \& Egyed 2007; Leboeuf 2013).

Our results (Tables 1 and 2) show that BoHV-4 infection has a very high prevalence in the samples obtained from Herds I and II. Because very few animals were sampled from Herds III and IV, we could not analyse the prevalence of BoHV-4 infection. However, our previous results and knowledge from veterinarians suggest that BoHV-4 infection is also increasing significantly in these herds, resulting in an increase in economic losses (Bilge-Dagalp 2007, 2008, 2011; Dağalp et al. 2012).

The pathogenesis of BoHV-4 infection has been questioned because of the detection of BoHV-4 from both healthy individuals and cattle with a wide variety of clinical signs (Monge et al. 2006; Wellenberg et al. 2000). In our study, out of 38 animals tested by PCR targeting the $g B$ gene region of BoHV-4, 25 animals, including aborting cows $(n=14)$ and aborted, stillborn and unviable calves $(n=11)$, tested positive for the virus. Because of the use of retrospective samples, different materials (blood, vaginal and placental samples) could be tested for aborting cows. However, it is not yet possible to say which of these materials should be used to diagnose BoHV-4 infection, although vaginal specimens appear superior to blood samples (Table 1). Similarly, several tissue samples from an aborted foetus gave positive results for BoHV-4, which indicate that BoHV-4 is transferred to the foetus transplacentally. In addition, isolation of BoHV-4 from a brain sample of a stillborn calf (animal No. 2 in Table 1) in another study (unpublished data) is very important for showing transplacental transfer and the virus' causative role in fertility problems. In short, our study has substantially determined a link between fertility problems such as abortion and stillbirths and BoHV-4 because we detected the virus in various foetal tissue samples, while the other studied pathogens, especially BVDV, were absent in most of the aborted foetuses (Tables 1 and 2). Verna et al. (2012) likewise concluded that the detection of BoHV-4 as a sole agent offers indirect evidence of the virus' involvement in bovine abortion.

Several reports indicate that BoHV-4 has an immunosuppressive effect (Egyed 2000; Egyed et al. 1996) and contributes to disease development by stimulating inflammatory reactions (Donofrio et al. 2005). Szenci et al. (2016) reported that local multiplication of Histophilus somni may produce certain chemicals (PGE2) that reactivate latent BoHV-4 from some local macrophages, while multiplication of the reactivated virus decreases the efficiency of local macrophage functions (opsonisation, antigen presentation and killing activity), which further promotes local bacteria multiplication. For this reason, we also tested all our samples for BVDV and BoHV-1, which are very common infections in Turkey, as well as for BoHV-4. The rate of detection of BVDV was as high as for BoHV-4 in Herd I, which had an acceptable sample size of aborting cows and foetuses for this assessment (Table 2). One of the six aborted foetuses was also co-infected with BoHV-4 and BVDV. However, it is not possible to conclude whether this signifies an interaction between BVDV and BoHV-4 infection in these cases, although BoHV-4 
has been identified as an important factor affecting the immune system. This could explain the high rates of these infections in Herds I and II. Based on our knowledge, few studies have investigated clinical cases, including abortions and the effects of BoHV-4 along or together with these other viruses. Yilmaz, Coskun and Sahin (2016) had reported that $66.66 \%$ of aborted calves (8/12) were positive for BVDV, although BoHV-1 and BoHV-4 were not detected in the sampled animals. Similarly, another study (Tuncer-Göktuna et al. 2016) using PCR analysis for investigating the role of herpes viruses and pesti-viruses in cases of ruminant abortion between 2007 and 2015 in western Turkey did not find BoHV-4 in any of the tested samples from 60 aborted foetuses, while two and 31 calves aborted analysed using ELISA were found positive for BoHV-1 and BVDV antigens, respectively. However, some other studies have reported the presence of BoHV-4 and its co-infection with other pathogens (Cvetojević et al. 2016; Frazier et al. 2002; Reed et al. 1979). Cvetojević et al. (2016) detected BoHV-4 in $21 \%$ of examined samples (21/100), co-infection of BoHV-4 with BVDV in two samples and one sample infected with Neospora caninum. Otherwise, several studies have proposed that BoHV-4 is a secondary agent, often associated with secondary bacterial infections (Chastant-Maillard 2015; Donofrio et al. 2008; Klamminger et al. 2017; Jacca et al. 2014; Nak et al. 2011) and also fungi or other viruses (Drolet, Werdin \& Goyal 1986; Fabian et al. 2008; Frazier et al. 2002). Gagnon et al. (2017) suggested that because BoHV-4 is a frequent risk or a secondary factor in cattle infections, higher BoHV-4 seroprevalence in cattle with respiratory or reproductive diseases could be expected. Thus, our data detecting two viral pathogens in the same aborted foetus, stillborn calves and aborting cows (Tables 1 and 2) are not surprising. Unfortunately, we were unable to test both foetuses and their mothers. Therefore, more detailed investigations are needed to establish a clear link between BoHV-4 infection and abortion as well as the potential interaction of BoHV-4 with other abortifacient pathogens in the same sample.

In this study, there were two main limiting factors. Firstly, it did not test for the presence of any additional microorganisms (bacteria, etc.). Secondly, it did not include serological results to show the positivity rate for BoHV-4 or the other studied viruses in aborting cows and/or healthy cattle in these herds.

In conclusion, we consider that BoHV-4 alone or in conjunction with other pathogens, especially BVDV, contributed to the development of the reproductive disorders reported in this study, and possibly to others as well. Further studies using epidemiological data from BoHV-4 infections and molecular characterisation of field BoHV-4 in different clinical cases are needed to understand their pathogenesis and responsibility for economic losses affecting cattle husbandry in Turkey.

\section{Acknowledgements Competing interests}

The authors have declared that no competing interests exist.

\section{Author's contributions}

All authors contributed equally to this work.

\section{Funding information}

This study was supported by a grant from the Scientific Research Projects (Project No: 20040810068 and 10B3338005), Ankara University.

\section{Data availability statement}

Data sharing is not applicable to this article as no new data were created or analysed in this study.

\section{Disclaimer}

The views and opinions expressed in this article are those of the authors and do not necessarily reflect the official policy or position of any affiliated agency of the authors.

\section{References}

Alkan, F., Bilge-Dagalp, S., Karapinar, Z., Timurkan, M.O. \& Coskun, N., 2018, 'Long-term study (2005-2010) on the vaccination with BoHV-1 glycoprotein E deleted marker vaccine in selected two dairy herds in Turkey', Tropical Animal Health and Production 50(2), 353-363. https://doi.org/10.1007/s11250-017-1440-3

Alkan, F. \& Burgu, I., 1993,'Investigation on the incidence of bovine viral diarrhoea virus calves born with encephalopathy in Turkey', Deutsche tierärztliche Wochenschrift 100(3), 107-109.

Alkan, F., Burgu, I., Bilge-Dagalp, S., Yildirim, Y., Gencay, A., Gungor, B. et al., 2005, 'The seroprevalence of BHV-1 infection on selected dairy cattle herds in Turkey', Revue de MedecineVeterinaire 156(3), 166-169.

Alkan, F., Ozkul, A., Bilge-Dagalp, S., Yesilbag, K., Oguzoglu, T.C., Akca Y. et al., 2009, 'Virological and serological studies on the role of PI-3 virus, BRSV, BVDV andBHV-1 on respiratory infections of cattle: I. The detection of etiological agents by direct immunofluorescence technique', Deutsche TierarztlicheWochenschrift 107(5), immunofler.

Altamlranda, E.G., Manrique, J.M., Perez, S.E., Rios, G.L., Odeon, A.C., Leunda, M.R. et al., 2015, 'Molecular characterization of the first Bovine Herpesvirus 4 (BoHV-4) strains isolated from in vitro bovine embryos production in Argentina', PLOS One strains isolated from in vitro bovine embryos production in Arge
100132212. https://doi.org/10.1371/journal.pone.0132212

Aslan, M.E., Azkur, A.K. \& Gazyagc, I.S., 2015, 'Epidemiology and genetic characterization of BVDV, BHV-1, BHV-4, BHV-5 and Brucella spp. infections in cattle in Turkey', The Journal of Veterinary Medical Science 77(11), 1371-1377. https://doi.org/10.1292/jvms.14-0657

Bilge-Dagalp, S., Can-Sahna, K., Yildirm, Y., Karaoglu, T., Alkan, F. \& Burgu, I., 2008 'Effects of bovine leucosis virus (BLV) infection on the bovine viral diarrhoea virus (BVDV) and bovine herpes virus 1 (BHV1) seroprevalences in dairy herds in Turkey', Revista de medicina veterinaria 159(7), 385-390.

Bilge-Dagalp, S., Demir, B., Gungor, E. \& Alkan, F., 2007, 'The seroprevalence of bovine herpesvirus type 4 (BoHV-4) infection with reproductive disorders', Revista de medicina veterinaria 158(4), 201-205.

Bilge-Dagalp, S., Oguzoglu, T.C., Faraji, A., Timurkan, M.O. \& Alkan, F., 2011, 'The investigation of BVDV, BoHV-4 and BoHV-1 as a possibleaetiological agents in abortion and neonatal death cases in cattle', The 8th ESVV pestivirus symposium in Hannover, Germany, September 25-28, 2011.

Chastant-Maillard, S., 2015, 'Impact of Bovine Herpesvirus 4 (BoHV-4) on reproduction', Transboundary and Emerging Diseases 62(3), 245-251. https://doi. org $/ 10.1111 /$ tbed.12155

Cvetojević, Đ., Savić, B., Milićević, V., Kureljušić, B., Jezdimirović, N., Jakić-Dimić, D. et al., 2016, 'Prevalence of Bovine herpesvirus type 4 in aborting dairy cows', Polish Journal of Veterinary Sciences 19(4), 731-736. https://doi.org/10.1515/ pjvs-2016-0092

Czaplicki, G. \& Thiry, E., 1998, 'An association exists between bovine herpesvirus-4 seropositivity and abortion in cows', Preventive Veterinary Medicine 33(1-4), 235-240. https://doi.org/10.1016/s0167-5877(97)00036-6

Dağalp, S.B., Alkan, F., Çalişkan, E., Yildirim, Y., Oguzoglu, T.C., Can Sahna, K. et al., 2012, 'The investigation of the herpesviruses (BoHV-1 and BoHV-4) on the occurrence of the reproductive disorders in dairy cattle herds, Turkey', Revue de médecine vétérinaire 163(4), 206-211.

Deim, Z., Szeredi, L. \& Egyed, L., 2007, 'Detection of bovine herpesvirus 4 DNA in aborted bovine fetuses', Canadian Journal of Veterinary Research 71(3), 226-229.

Donofrio, G., Colleoni, S., Galli, C., Lazzari, G., Cavirani, S. \& Flammini, C.F., 2005 'Susceptibility of bovine mesenchymal stem cells to bovine herpesvirus 4 ', Journal of Virological Methods 127(2), 168-170. https://doi.org/10.1016/j. jviromet.2005.02.019 
Donofrio, G., Ravanetti, L., Cavirani, S., Herath, S., Capocefalo, A. \& Sheldon, I.M. 2008, 'Bacterial Infection of endometrial stromal cells influences bovine herpersvirus 4 immediate early gene activation: A new insight into bacterial and viral interaction for uterine disease', Reproduction (Cambridge, England) 136(3), viral interaction for uterine disease', Reproduc
361. https://doi.org/10.1530/REP-08-0171

Drolet, R., Werdin, R. \& Goyal, S. 1986., 'The role of bovine herpesvirus type-4 (DN 599) infection in Minnesota cattle', Proceeding of the annual meeting of American Association of veterinary laboratory diagnosticians 29, 335-346.

Dubuisson, J., Thiry, E., Bublot, M., Thomas, I., Van Bressem, M.F., Coignoul, F. et al., 1989, 'Experimental infection of bulls with a genital isolate of bovine herpesvirus-4 and reactivation of latent virus with dexamethasone', Veterinary Microbiology 21(2), 97-114. https://doi.org/10.1016/0378-1135(89)90022-9

Egyed, L., 2000, 'Bovine herpesvirus type 4: A special herpesvirus', Acta Veterinaria Hungarica 48(4), 501-513. https://doi.org/10.1556/004.48.2000.4.13

Egyed, L., Ballagi-Pordány, A., Bartha, A. \& Belák, S., 1996, 'Studies of in vivo distribution of bovine herpesvirus type 4 in the natural host', Journal of Clinical Microbiology 34(5), 1091-1095.

Fabian, K., Makrai, L., Sachse, K., Szeredi, L. \& Egyed, L. 2008,'An investigation of the aetiological role of bovine herpesvirus 4 in bovine endometritis', The Veterinary Journal 177(2), 289-292. https://doi.org/10.1016/j.tvjl.2007.04.010

Frazier, K.S., Baldwin, C.A., Pence, M., West, J., Bernard, J., Liggett, A. et al., 2002 'Seroprevalence and comparison of isolates of endometriotropic bovine herpesvirus-4', Journal of Veterinary Diagnostic Investigation 14(6), 457-462. https://doi.org/10.1177/104063870201400602

Gagnon, C.A., Traesel, C.K., Music, N., Laroche, J., Tison, N., Auger, J.P. et al., 2017 'Whole genome sequencing of a Canadian bovine gammaherpesvirus 4 strain and the possible link between the viral infection and respiratory and reproductive clinical manifestations in dairy cattle', Frontiers in Veterinary Science 4(1), 92 https://doi.org/10.3389/fvets.2017.00092

Goltz, M., Broll, H., Mankertz, A., Weigelt, W., Ludwig, H., Buhk, H.J. et al., 1994 'Glycoprotein B of bovine herpesvirus type 4: Its phylogenetic relationship to gB equivalents of the herpesviruses', Virus Genes 9(1), 53-59. https://doi. org/10.1007/BF01703435

Goyal, S.M. \& Naeem, K., 1992, 'Bovid Herpesvirus-4: A review', The Veterinary Bulletin 62, 181-210.

ICTV, 2017, International Committee on Taxonomy of Viruses, viewed 20 October 2017, from https://talk.ictvonline.org/taxonomy/.

Izumi, Y., Tsuduku, S., Murakami, K., Tsuboi, T., Konishi, M., Onishi, M. et al. 2006 'Characterization of bovine herpesvirus type 4 isolated from cattle with mastitis and subclinical infection by the virus among cattle', The Journal of Veterinary Medical Science 68(2), 189-193. https://doi.org/10.1292/jvms.68.189

Jacca, S., Franceschi, V., Agosti, M., Cavirani, S., Mistretta, F. \& Donofrio, G., 2014 Interferon gamma-mediated BoHV-4 replication restriction in bovine endometria stromal cells is host IDO1 gene expression independent and BoHV-4 IE2 gene expression dependent', Biology of Reproduction 91(5), 112. https://doi. org/10.1095/biolreprod.114.123000

Kirkbride, C.A., 1992, 'Etiologic agents detected in a 10-year study of bovine abortions and stillbirths', Journal of Veterinary Diagnostic Investigation 4(2), 175-180. https://doi.org/10.1177/104063879200400210

Klamminger, S., Prunner, I., Giuliodori, M.J. \& Drillich, M., 2017, 'Uterine infection with bovine herpesvirus type 4 in dairy cows', Reproduction in Domestic Animals 52(1) 115-121. https://doi.org/10.1111/rda.12865

Leboeuf, C., 2013, 'Six percent of abortions are PCR positive for BoHV-4 in the department of La Manche', Point Vétérinaire 44(332 Part 2), 60-64.

McKercher, D.G. \& Wada, E.M., 1964, 'The virus of infectious bovine rhinotracheitis as a cause of abortion in cattle', Journal of the American Veterinary Medical Association 144(1), 136-142.

Miller, J.M. \& Van der Maaten, M.J., 1987, 'Early embryonic death in heifers after inoculation with bovine herpesvirus- 1 and reactivation of latent virus in reproductive tissues', American Journal of Veterinary Research 48(11), 1555-1558.

Miyano, H., Haritani, M., Sentsui, H., Tsuboi, T., Tanimura, N., Kimura, K.K. et al., 2004 , 'Mammary lesions associated with bovine herpesvirus Type 4 in a cow with clinical mastitis', The Journal of Veterinary Medical Science 66(4), 457-460. https://doi.org/10.1292/jvms.66.457

Monge, A., Elvira, L., Gonzalez, J.V., Astiz, S. \& Wellenberg, G.J., 2006, 'Bovine herpesvirus 4-associated postpartum metritis in a Spanish dairy herd', Research in Veterinary Science 80(1), 120-125. https://doi.org/10.1016/j.rvsc.2005.04.001

Murray, R.D., 1990, 'A field investigation of causes of abortion in dairy cattle', Veterinary Record 127(22), 543-547.
Naeem, K., Goyal, S.M. \& Werdin, R.E., 1989, 'Prevalence of bovid herpesvirus-4 and its antibody in cattle in Minnesota', American Journal of Veterinary Research 50(11), 1931-1935.

Nak, Y., Dagalp, S.B., Cetin, C., Nak, D., Alkan, F., Borum, E. et al., 2011, 'Course and severity of postpartum metritis cases following antibiotic and PGF2 $\alpha$ administration in postpartum metritis cows infected with BoHV-4', Transboundary and Emerging Diseases 58(1), 31-36. https://doi.org/10.1111/j.1865-1682.2010. 01174. $\mathrm{x}$

Nikolin, V.M., Donofrio, G., Milosevic, B., Taddei, S., Radosavljevic, V. \& Milicevic, V., 2007, 'First Serbian isolates of bovine herpesvirus 4 (BoHV-4) from a herd with a history of postpartum metritis', The New Microbiologica 30(1), 53.

Nikolin, V., Vesna, M. \& Radosavljević, V., 2008, 'Presence of bovine herpesvirus type 4 (BHV-4) infection in bulls for artificial insemination in Serbia', Acta Veterinaria 58(2-3), 267-273. https://doi.org/10.2298/AVB0803267N

Oğuzoğlu, T.C., Muz, D., Yilmaz, V., Timurkan, M.Ö., Alkan, F., Akça, Y. et al., 2012, 'Molecular characteristics of bovine virus diarrhoea virus 1 isolates from Turkey: Approaches for an eradication programme', Transboundary and Emerging Diseases 59(4), 303-310. https://doi.org/10.1111/j.1865-1682.2011.01272.x

Reed, D.E., Langpap, T.J. \& Bergeland, M.E., 1979, 'Bovine abortion associated with mixed Movar 33/63 type herpesvirus and bovine viral diarrhea virus infection', The Cornell Veterinarian 69(1), 54-66.

Sambrook, J., Fritsch, E.F. \& Maniatis, T., 1989, 'Molecular cloning', in J. Sambrook, E.F. Fritsch \& T. Maniatis (eds.), A laboratory manual, pp. 914-923, Cold Spring Harbor Laboratory Press, New York.

Schiefer, B., 1974, 'Bovine abortion associated with cytomegalovirus infection', Zentralb/ Veterinarmed B 21(3), 145-151. https://doi.org/10.1111/j.1439-0450. Zentralb/ Veterinar.to0486.x

Szenci, O., Sassi, G., Fodor, L., Molnár, L., Szelényi, Z., Tibold, J. et al., 2016, 'Co-infection with bovine herpesvirus 4 and Histophilus somni significantly extends the service period in dairy cattle with purulent vaginal discharge', Reproduction in Domestic Animals 51(1), 143-149. https://doi.org/10.1111/rda.12658

Tan, M.T., Karaoglu, M.T., Erol, N. \& Yildirim, Y., 2006, 'Serological and virological investigations of bovine viral diarrhoea virus (BVDV) infection in dairy cattle herds in Aydin province', Turkish Journal of Veterinary and Animal Sciences 30(3), 299-304.

Thiry, E., Dubuisson, J., Bublot, M., Van, M.B. \& Pastoret, P.P., 1990, 'The biology of bovine herpesvirus-4 infection of cattle', Deutsche tierarztliche Wochenschrift 97(2), 72-77.

Tuncer-Göktuna, P., Alpay, G., Öner, E.B. \& Yeşilbağ, K., 2016, 'The role of herpesviruses (BoHV-1 and BoHV-4) and pestiviruses (BVDV and BDV) in ruminant abortion cases in western Turkey', Tropical Animal Health and Production 48(5), 1021-1027. https://doi.org/10.1007/s11250-016-1050-5

Van Engelenburg, F.A., Maes, R.K., Van Oirschot, J.T. \& Rijsewijk, F.A., 1993, 'Development of a rapid and sensitive polymerase chain reaction assay for detection of bovine herpesvirus type 1 in bovine semen', Journal of Clinical Microbiology 31(12), 3129-3135.

Verna, A.E., Manrique, J.M., Pérez, S.E., Leunda, M.R., Pereyra, S.B., Jones, L.R. et al. 2012, 'Genomic analysis of bovine herpesvirus type 4 (BoHV-4) from Argentina: High genetic variability and novel phylogenetic groups', Veterinary Microbiology 160(1-2), 1-8. https://doi.org/10.1016/j.vetmic.2012.04.039

Vilcek, S., Nettleton, P.F., Paton, D.J. \& Bel, S., 1997, 'Molecular characterization of ovine pestiviruses', Journal of General Virology 78(4), 725-735. https://doi. ovine pestiviruses', Journal of G
org/10.1099/0022-1317-78-4-725

Wellemans, G., Van Opdenbosch, E. \& Mammerickx, M., 1986, 'Experimental inoculation of bovine herpesvirus 4 (strain LVR 140) in pregnant and non-pregnant cows', Annales de recherches veterinaires 17(1), 89-94.

Wellenberg, G.J., Van Der Poel W.H.M., Van Der Vorst T.J.K., Van Valkengoed P.H.R., Schuhken, Y.H., Wagenaar, F. et al., 2000, 'BoHV-4 in bovine clinical mastitis', Veterinary Record 147(8), 222-225. https://doi.org/10.1136/vr.147.8.222

Wellenberg, G.J., Verstraten, E.R.A.M., Belak, S., Verschuren, S.B.E., Rijsewijk, F.A.M. Peshev, R. et al., 2001, 'Detection of bovine herpesvirus 4 glycoprotein B and thymidine kinase DNA by PCR assays in bovine milk', Journal of Virological Methods 97(1-2), 101-112. https://doi.org/10.1016/s0166-0934(01)00341-x

Yildirim, Y., Yilmaz, V., Kalaycioglu, A.T., Dagalp, S.B., Majarashin, A.R.F., Celebi, O. et al., 2011, 'An investigation of a possible involvement of BVDV', BHV-1 and BHV-4 infections in abortion of dairy cattle in Kars district of Turkey', Kafkas Üniversitesi Veteriner Fakültesi Dergisi 17(6), 879-883.

Yilmaz, V., Coskun, N. \& Sahin, M., 2016, 'Molecular detection of Bovine Herpes Virus-1 (BoHV-1), Bovine Herpes Virus-4 (BoHV-4) and Bovine Viral Diarrhoea Virus (BVDV) in aborted ruminant fetuses from Kars province in Northeast Turkey', Indian Journal of Animal Research 50(4), 551-556. https://doi.org/10.18805/ijar.9372 